DOI: $10.20472 / E S .2016 .5 .2 .001$

\title{
DOES USING NAIRU IN THE PRODUCTION FUNCTION INFLUENCE ESTIMATION OF POTENTIAL OUTPUT AND OUTPUT GAP?
}

\author{
DANA KLOUDOVÁ
}

\begin{abstract}
:
Although there are more sophisticated methods of estimation of output gap and potential output, a production function still remains among the most used methods of estimation of these unobservable variables. To gain the most reliable data, several versions of the production function have been developed. This paper analyses if there is some difference between using a version of production with HP filter applied during the estimation and NAIRU. Results will show that there are not very significant differences but because NAIRU can explain changes at the labour market better it will be recommended to use this version of production function.
\end{abstract}

\section{Keywords:}

production function, NAIRU, output gap, potential product

JEL Classification: E22, E24, E32

\section{Authors:}

DANA KLOUDOVÁ, University of Economics, Prague, the Czech Republic, Email: dana.kloudova@vse.cz

\section{Citation:}

DANA KLOUDOVÁ (2016). DOES USING NAIRU IN THE PRODUCTION FUNCTION INFLUENCE ESTIMATION OF POTENTIAL OUTPUT AND OUTPUT GAP?. International Journal of Economic Sciences, Vol. V(2), pp. 1-21., 10.20472/ES.2016.5.2.001 


\section{Introduction}

Output gap with the potential output are very important macroeconomic variables which are used by many central banks for many purposes. The most they are used for evaluation of current state of economy and by some monetary policy decisions to gain the macroeconomic variables on their natural levels. Therefore it is very important to work with as reliable data as possible because incorrectly estimated data of these variables can influence further macroeconomic calculations negatively. But the problem is that both potential product and output gap are unobservable variables which cannot be measured with the absolute reliability.

To increase the credibility of gained estimations of these two unobservable variables, there have been invented several methods of estimation of output gap and potential output. In general, this quite a large amount of possible methods of estimation can be divided into three main groups. The first group, univariate methods, (and the oldest, too) is characterised by quite simple methods of estimations. The big advantage of this group of estimation is its ease on required data. All methods need only seasonally adjusted time series of GDP. But on the other hand, this group has quite big disadvantages, too. The big one lies in its pure statistical character which abstract away from some economic models or theories that could explain the progress of output gap and potential output more precisely. Other assumptions of some methods from this group are not compatible with the reality either. For example by the linear trend the growth of potential output is not constant. Hodrick - Prescott filter (1997) has so called end-point problems (this holds for other univariate statistical filters, too). Into this group belong for example these methods: Baxter - King filter (1999), ChristianoFitzgerald filter (1999) or Hodrick-Prescott filter (1997) which still belongs among the most frequently used methods of estimation of potential output and output gap.

More sophisticated methods of estimation of output gap and potential output are structural methods which are represented mainly by production functions and structural VAR models (SVAR). In comparison with the univariate methods, structural methods include some economic model or theories which can explain progress of potential output and output gap more precisely. The disadvantage of these methods is their demands on required data. In addition, unlike production functions, estimation output gap with SVAR models is quite exact.

Although there are more sophisticated methods of estimation of output gap, like multivariate (mainly multivariate Hodrick - Prescott filter (1997), multivariate unobserved component model (MVUC) or multivariate Beveridge - Nelson decomposition (1981)), these methods are not utilized so often as univariate HP filter or production functions. Explanation of this trend (e.g. Hjelm and Jönsson (2010) or De Masi (1997)) is the requirements for selection of the suitable variables used for the estimation (especially when we want compare economies where some data are not accessible) and demands of the methods on used data. Estimations themselves are more complicated than construction of HP filter or production function (mainly because 
of higher data requirements and procedure of estimation itself which consists of several steps).

In these days, despite the existence of the most sophisticated methods of estimation like multivariate MVUC model or multivariate HP filters, production functions remain as one of the most frequently used methods of estimation of potential output and output gap, used by many national and international organisations. This paper will deal with the production function as the method of estimation of potential output and output gap for the Czech economy from 1998Q1 to 2015Q2. The aim of this paper is to answer the question, if more sophisticated method of computation potential employment with using NAIRU will bring more accurate estimations of output gap and potential output than a simplified model of production function using quite simple method of computation of potential employment as part of the production function. It will be shown that the differences will be not substantial.

The structure of the paper is as follows: chapter one will deal with the previous research of estimation of output gap for the Czech economy with the production functions. It will be mentioned that there are only a few papers dealing with this issue. Chapter two brings information about required and used data in this analysis. Next chapter will introduce two versions of production functions. Firstly, the quite simple version with the simple calculations will be shown and then, the more sophisticated calculation with using NAIRU will be analysed. Chapter four will bring results of analysis. The two output gaps will be compared and analysed. Potential output estimated by the two above mentioned methods will be compared with the actual product. It will be shown, that the differences between these two estimations are not very substantial. In the contrary to some studies (e.g. de Brouwer (1998)) there did not occur the situation that two versions of estimation of output gap brought different progress of business cycle. Other statistics (average, median, minimum, maximum, standard deviation, correlation and concordance coefficient) and calculation of contribution of total factor productivity, labour and capital to the growth of the potential product will confirm the similarity of the two estimations of output gaps. In the end, the growth of potential output of the two estimations will be compared, too.

\section{Previous research}

Production function and output gap are variables which are not able to be calculated with the maximal accuracy. In addition, there are more definitions associated with these unobservable variables. There is then the uncertainty which definition is the correct one. For example, Okun (1962) defined potential output as the maximal output which can be produced in the economy by the unemployment rate 4\%. Artus (1977) defined this unobservable variable as the maximal product that can be produced by the maximal utilization of labour force and capital, but their utilization must be utilized with the "normal pressure"2. In this paper, the potential output will be defined according to de Masi (1997) as the maximal product that can be produced in the economy without

\footnotetext{
${ }^{2}$ Author has not explain how to define the "normal pressure“ yet.
} 
inflationary pressures. Under the term output gap will be then understood a deviation of the real output from the potential output, measured as the percentage of the potential output.

Except for studies dealing with the several approaches of estimation (e. g- Slevin (2001), de Brouwer (1998). Kenny (1995), St. Amant, P. and van Norden, S. (1997) or Cerra, V. and Saxena S. C. (2000), there are some studies analysing an impact of NAIRU on the estimation of the output gap. Doménech and Gomez (2003) estimated output gap, NAIRU, Okun's law and Phillip's curve for the United States, Sramkova (2010) estimated output gap and NAIRU within state-space framework for Slovakia. NAIRU was used by Chagny and Dopke (2001), too. Cui, Härdle and Wang (2015) calculated NAIRU with inflation expectation data. Output gap and inflation in the EU tested Bolt and van Els (1998). For the Czech Republic, there are only a few papers dealing with the estimation of potential output and output gap, especially with the using of the production function. Among the first studies analysing the estimation output gap for the Czech economy belong the study from Hájek and Bezděk (2000). Beside this method of estimation of the output gap, authors used HP filter, too. The authors solved the problem how to calculate potential employment with the application of the HP filter on the time series. More sophisticated method used Hurník a Navrátil (2005), when they used calculation of NAIRU to estimate potential output for the Czech economy during $1994-2003$. However, the authors did not compare their results with the other methods of estimation. They simply claimed, that their method will explain the changes at the labour market more correctly. The first study, which analysed the impact of the variable capital-to-output ratio on the estimation of the output gap for the Czech Republic, was written by Hájková and Hurník (2007). They showed that the difference between results with the constant and variable capital-to-output ratio were not significant. Other studies estimated output gap for the Czech republic with different methods, for example Dybzcak, Flek, Hájková a Hurník (2006), Beneš and N'Diaye (2004), who used multivariate unobserved component model, or Plašil (2011), who analysed univariate HP filter. From newer studies we can mentioned e. g. Kloudová (2013a) who analysed ability of output gap for the Czech republic (methods of estimation were HP filter, SVAR model and multivariate unobserved component model) to indicate inflation. In other study Kloudová (2013b) estimated Czech output gap with univariate and multivariate unobserved models.

\section{Data}

In relation to the univariate statistical methods, production function is far more demanding on the input data, what is a big disadvantage of this method of estimation of potential output and output gap. To estimate output gap and potential output with this method, real output (GDP) was used. It was seasonally adjusted. To calculate actual capital stock, we used capital stock from previous years and actual gross fixed investments. Other required data for the estimations were total nominal labour costs, total employment and total value added in the economy. All used data were downloaded from a statistical database of OECD. Due to the unreliability of required 
data in the beginning of the selected time period ${ }^{4}$, the time period starts from 1998Q1. The analysed time series was from 1998Q1-2015Q1. All data had a quarterly periodicity.

\section{Model}

Output gap for the Czech Republic was estimated with the production function according to Giornio et al. (1995). Both estimates of the output gap and potential output will be estimated according to this model. Both parameters $\alpha$ and $\beta$ will be calculated in the same way for both estimations, too. The selected version of the production function is the Cobb - Douglas production function with two variables with Hicks - neutral technical progress:

$$
Y_{t}=A_{t} L_{t}^{\alpha} K_{t}^{\beta}
$$

where $Y_{t}$ represents seasonally adjusted real output, $L_{t}$ labour force, $K_{t}$ capital and $A_{t}$ means total factor productivity (TFP). Some restrictions were applied into the selected models: the production function will have constant elasticity of substitution (so called CES function), which equals $1 .^{5}$ Another assumption of the model is a positive and decreasing marginal product of inputs of labour and capital. So parameters $\alpha$ and $\beta$ will reach values only between $0-1$, while holds this relationship: $\alpha+\beta=1$.

For the purpose of the analysis of this paper, both parameters $\alpha$ and $\beta$ were set as a constant. ${ }^{6}$ Marginal product of labour will be defined as $\frac{\partial Y}{\partial L}=w$, marginal product of capital as $\frac{\partial Y}{\partial K}=r$. For Cobb - Douglas production function with the constant capital-tooutput ratio and labour-to-output ratio, it will be used the following relationship: $Y=$ $w L+r K$, while for parameters $\alpha$ and $\beta$ hold, that: $\alpha=\frac{w L}{Y}$ a $\beta=\frac{r K}{Y}$.

To calculate the parameters $\alpha$ and $\beta$, a study from Dybczak et al. (2006) was selected from the quite large studies. Parameter $\alpha$ was calculated as a ratio of total costs on labour and product:

$$
\alpha_{t}=\frac{T L C_{t} \cdot L_{t}}{G V A_{t}}
$$

\footnotetext{
${ }^{4}$ In general, all data for developing economies from the Eastern Europe were considered to not be reliable, therefore many international institutions start with the 1995/6 Q1.

${ }^{5}$ An assumption according to Giornio et. al (1995).

${ }^{6}$ Many studies work with the constant parameters $\alpha$ and $\beta$, we can mention e.g. Konuki (2008), who used a constant value of parameter $\alpha(\alpha=0,52)$ calculated by the Ministry of Finance of Slovakia to estimate potential output and output gap for Slovak economy. Oomes a Dynnikova (2006) used a constant value $\alpha=0.52$ from previous research to estimate potential output and output gap for economy of Russia. But there are only a few studies dealing with the variable parameters $\alpha$ and $\beta$ . Hájková and Hurník (2007) introduced this assumption into the estimation of potential output and output gap because they stated a hypothesis that the Czech economy has not reached its steady state yet. Nevertheless the results of calculation with the constant or variable parameter $\alpha$ would bring not very substantial differences.
} 
where $T L C_{t}$ represents total nominal labour costs, $L_{t}$ potential employment and $G V A_{t}$ total value added in the economy. Parameter $\beta$ is then calculated from the equation $\beta=(1-\alpha)$.

Calculated value of the parameter $\alpha$, that we will calculated in this paper, with is $0.57169^{7}$.

Another problem connected with the input data is a potential capital stock. Because it was not possible to gain required data from some database, an approach according to Denis et al. (2006) was chosen. This approach supposes that capital will be utilized at the most only when it would be the potential capital stock. Also an assumption of perpetual inventory method (PIM) was invented into the model. Actual capital stock will be then defined as the sum of previous capital stock decreased of depreciation and current real fixed investments. The value of depreciation rate was stated according to Mourre (2009), $\delta=0.05$. Capital stock for the Czech economy during 1998Q1-2015Q2 was calculated as follows:

$$
K_{t}=K_{t-1} \cdot(1-0,05)^{0,25}+G F C F_{t}
$$

where $\mathrm{K}$ is capital stock and GFCF are gross fixed investments.

\section{Version 1:}

Until this point, procedure of estimation output gap and potential output with the two versions of production function was the same. The main difference between these two analysed versions of the production function will lie mainly in the method of calculation of the potential employment. The first version represents a quite simple approach which is still selected by many authors nowadays (e.g. Bezděk and Hájek (2000), Zimková and Bachorovský (2007), Konuki (2008) and others). It is quite a simple approach that uses application of a simple univariate statistical filter on a given time series. In this paper, univariate HP filter was applied to estimate potential employment.

To estimate potential output and output gap, it is necessary to gain the variable total factor productivity (TFP) which is unable to be measured directly. Therefore it is usually calculated as a Solow residuals. The gross TFP will be comprised of two components: a long-term TFP and a short-term cyclical TFP.

TFP is calculated from the equation (1) as follows:

$$
A_{t}=\frac{Y_{t}}{L_{t}^{\alpha} K_{t}^{1-\alpha}}
$$

where $Y_{t}$ is seasonally adjusted GDP, $L_{t}$ is labour force measured as total employment and $K_{t}$ are capital inputs measured as a capital stock. Then potential levels of this

\footnotetext{
${ }^{7}$ The value is calculated as an average of the calculated values. This approach is common by many institutions (e.g. OECD, IMF, Ministry of Finance, and many studies (e.g. Konuki (2008) used similar method of obtaining of this variable. Naturally, it is possible to caluculate variable parameter, but there are not many studies working with this assumption (e.g. Hájková and Hurník (2007)).
} 
variable must be obtained. One of the methods how to get them is using some statistical filter, but it would lead to a negative fact that a production function would contain disadvantages connected with the statistical filters that have been mentioned above in this paper. The univariate HP filter was applied on TFP for the Czech economy in this paper. Because we work with the quarterly data, a smooth parameter $\lambda=1600$ was chosen.

When we obtained potential level of TFP, capital stock and potential unemployment, we could approach the final estimation of potential output according to the following equation ${ }^{8}$ :

$$
Y_{t}^{*}=A_{t}^{*} L_{t}^{\alpha} K_{t}^{\beta}
$$

Output gap estimated with the production function, when potential employment was calculated by application of HP filter on a given time series, is shown in the Figure 1. An abbreviation "gap_pf1" means output gap estimated according to the first version of production function.

\footnotetext{
${ }^{8}$ The symbol * means a potential level of a variable
} 


\section{Figure 1: Output gap - production function without NAIRU}

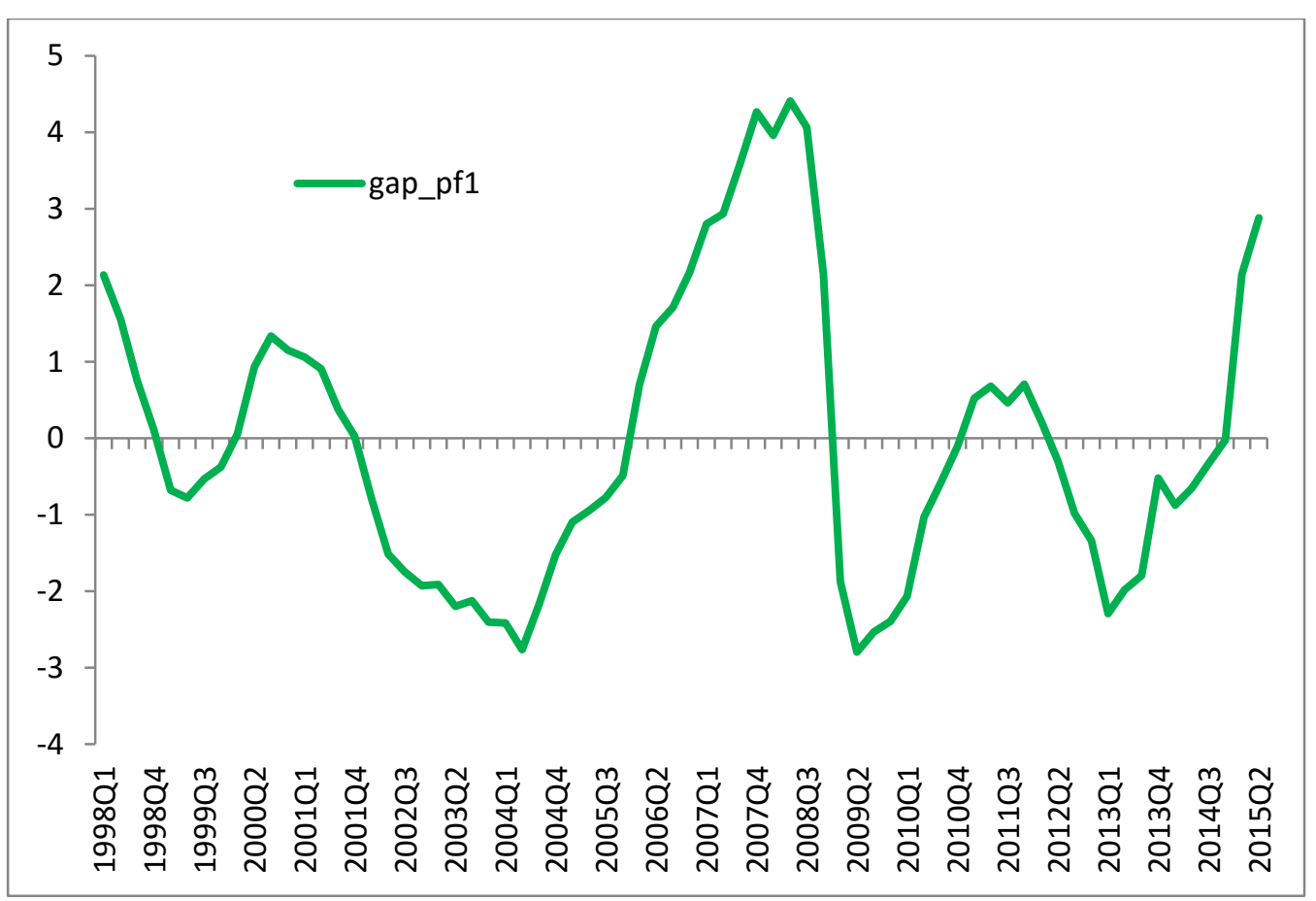

Source: author's own figures, data from OECD

\section{Version 2 - Estimation of NAIRU:}

The second method how to gain a potential level of employment is to calculate it with using a concept of NAIRU. This process consists in several steps. The first one was to calculate NAIRU, or nonaccelerating rate of unemployment. To this purpose, two steps of calculations according to Epstein a Macchiarelli (2010) were used.

The first step of the calculation was Kalman decomposition of unemployment, which defines unemployment as a sum of a stochastical trend component $\bar{U}_{t}$ and cyclical component $\mathrm{G}_{\mathrm{t}}$ :

$$
U_{t}=\overline{\mathrm{U}}_{t}+G_{t}
$$

while for the potential component holds:

$$
\overline{\mathrm{U}}_{t}=\mu_{t}+\overline{\mathrm{U}}_{t-1}+\eta_{t}
$$

Potential unemployment is then described with the process of random walk with a drift. The drift is able to be stochastical and for residuals holds $\eta_{t} \sim N\left(0, \sigma_{\eta}^{2}\right)$. So, when holds $\sigma_{\eta}=0$, NAIRU does not change over time. To enable long-term unemployment rate to be variable over time, an assumption according to Gordon (1996) and Epstein 
a Macchiarelli (2010) was implemented: $\sigma_{\eta}=0,1$. Cyclical component $\mathrm{G}_{\mathrm{t}}$ is defined according to Fabiani and Mestre (2004) as follows ${ }^{9}$ :

$$
G_{t}=\phi_{1} G_{t-1}+\phi_{2} G_{t-2}+\psi_{t}
$$

Cyclical component and trend are considered to be unobservable and are estimated by Kalman filter.

In the second step, the cyclical component $G_{t}$ is identified with the utilisation of a Phillips curve ${ }^{10}$ :

$$
\Delta \pi_{t+1}=\gamma+\alpha(L) \Delta \pi_{t}+\rho(L) G_{t}+\beta(L) Z_{t}+\varepsilon_{t}
$$

where $\alpha(L), \rho(L)$ and $\beta(L)$ are polynomials in lag operators 2,0 and 1. $\Delta \pi_{t+1}$ represents changes in unemployment rate at the time $t+1$ and $Z_{t}$ supply shock including changes in import prices. The equation (7) will be started according to Epstein a Macchiarelli (2010) with least squares method (LSM), where unemployment gap is approximated with the cyclical component of the unemployment that was obtained in the step one. Cyclical component of the unemployment $G_{t}$ is estimated as follows, while it is considered to be an unobservable variable.

Table 1 shows quarterly data of unemployment rate and results of estimations obtained from the steps one and two. For comparison, there have been included data of potential and cyclical rate of unemployment obtained from the application of univariate HP filter on the time series. Because the data have a quarterly periodicity, a smooth parameter $\lambda=1600$ was used. In order to achieve better readability, only selected data were included into the table ${ }^{11}$.

\footnotetext{
${ }^{9}$ It holds that $\phi_{1}+\phi_{2}<1$
}

\footnotetext{
${ }^{10}$ Cyclical component $\mathrm{G}_{\mathrm{t}}$ is explained in the equation 8 .

${ }^{11}$ For further informations about the model of NAIRU, look Epstein a Macchiarelli (2010). There is no space for detailed description in the paper due to the required limit of its length.
} 
Table 1: Trend and cyclical components of unemployment

\begin{tabular}{|c|c|c|c|c|c|c|c|c|c|c|}
\hline & 1998Q1 & 2000Q1 & 2002Q2 & 2004Q1 & 2006Q1 & 2008Q1 & 2010Q1 & 2012Q1 & 2014Q1 & 2015Q1 \\
\hline Unemployment rate & 5,8 & 9,2 & 7,4 & 8,4 & 7,6 & 4,6 & 7,7 & 6,8 & 6,5 & 5,7 \\
\hline \multicolumn{11}{|l|}{$\underline{\text { Trend }}$} \\
\hline $\begin{array}{l}\text { Kalman's } \\
\text { decomposition }\end{array}$ & 7,3 & 8,0 & 8,1 & 7,8 & 7,0 & 6,2 & 6,5 & 6,7 & 6,2 & 5,8 \\
\hline HP filter & 6,6 & 8,4 & 8,0 & 8,0 & 7,1 & 5,5 & 6,6 & 7,0 & 6,4 & 5,5 \\
\hline \multicolumn{11}{|l|}{ Cyclical component } \\
\hline $\begin{array}{l}\text { Kalman's } \\
\text { decomposition }\end{array}$ & $-1,5$ & 1,2 & $-0,7$ & 0,7 & 0,6 & $-1,6$ & 1,2 & 0,1 & 0,3 & $-0,1$ \\
\hline HP filter & $-0,8$ & 0,8 & $-0,6$ & 0,4 & 0,5 & $-0,9$ & 1,1 & $-0,2$ & 0,1 & 0,2 \\
\hline
\end{tabular}

Source: author's own figures, data from OECD

Figure 2: actual unemployment and NAIRU

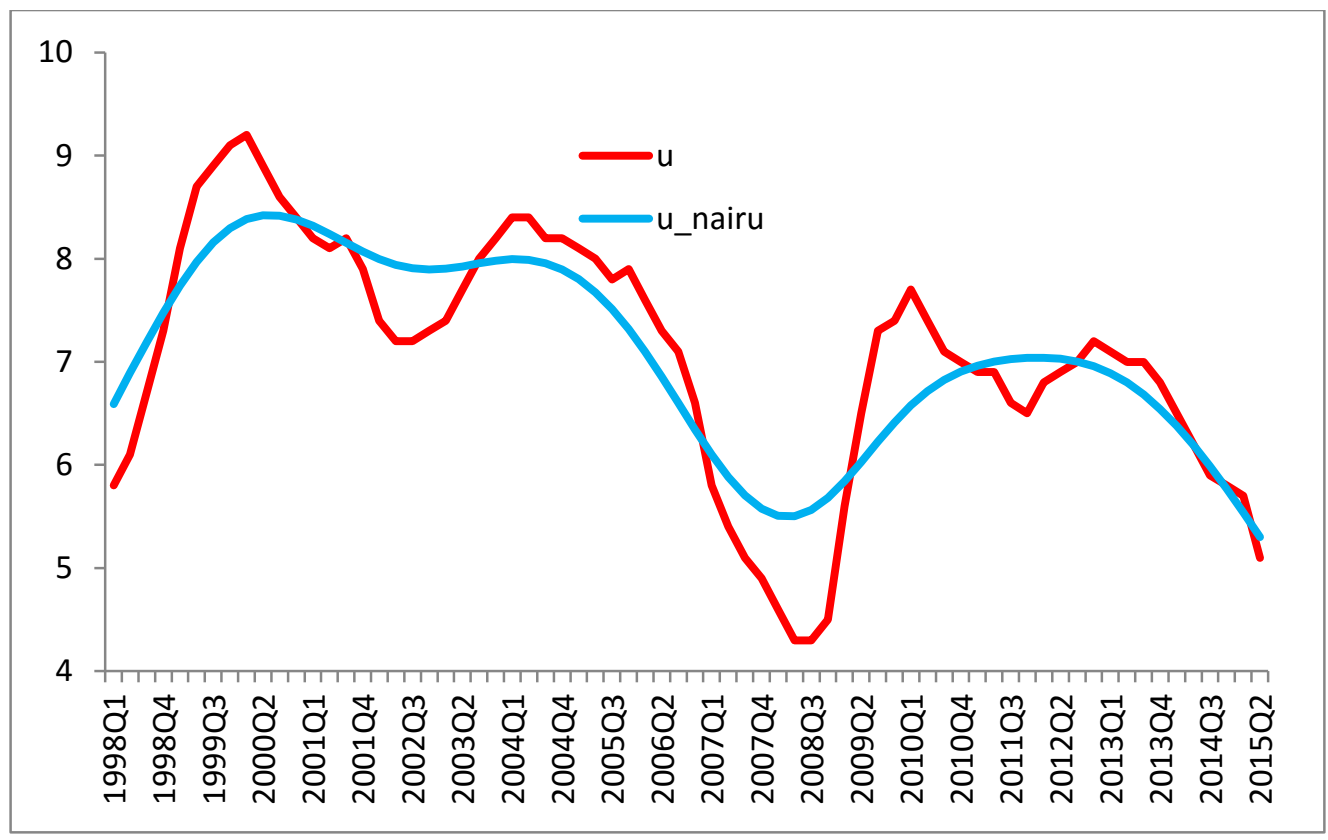

Source: author's own figures, data from OECD 
Calculated NAIRU for the Czech Republic between 1998Q1 - 2015Q2 is shown in the figure No. $2 .{ }^{12}$ One can see that on the start of the analysed time series, there was the real unemployment lower than NAIRU but following worsening of economic situation causes its increase. In 2008 - 2009, the unemployment rate reached its lowest level during the analysed time series but in the next quarters it increases dramatically to its maximum because of world economic crisis. In the last years, situation at the labour market improved, unemployment rate had a decreasing trend and predictions were positive, too.

Now it is possible to calculate potential employment $L^{*}{ }_{t}$ as follows:

$$
L_{t}^{*}=\operatorname{active}_{t}+P R_{t}^{*}(1-N A I R U)
$$

where active $_{t}$ is population in working age 15-64 years, $P R_{t}^{*}$ is trend of rate of participation. According to Epstein and Macchiarelli (2010), it is recommended to input this equation into the model of production function because changes in population in the working age, rate of participation and NAIRU can explain better changes in the potential employment. We can expect too, that this reflects better changes in the economy. To realize estimation of potential output and output gap, it is necessary to gain total factor productivity TFP. Due to the impossibility to calculate it directly, this variable will be calculated as Solow residual. Gross TFP is divided into two components: a long-term component of the TFP and a short-term cyclical component of TFP. TFP can be derived then from the equation (6) as follows:

$$
A_{t}=\frac{Y_{t}}{L_{t}^{\alpha} K_{t}^{1-\alpha}}
$$

where $Y_{t}$ is real GDP, $L_{t}$ are labour inputs calculated as total employment and $K_{t}$ are capital inputs measured as a capital stock. The further step was to estimate the potential level of this variable while results of this calculation is influenced by the selected method of smoothing. The univariate HP filter was selected to obtain the potential level of TFP. Due to the used quarterly data, smoothing parameter $\lambda=1600$ was applied. ${ }^{13}$

After obtaining of potential TFP, capital stock and potential employment, we can estimate potential output according to the following equation:

$$
Y_{t}^{*}=A_{t}^{*} L_{t}^{\alpha} K_{t}^{\beta}
$$

where $Y_{t}^{*}$ represents potential output.

\footnotetext{
${ }^{12}$ An abbrevation „u“ means unemployment for the Czech Republic between 1998Q1-2015Q2, „u nairu“ then nonaccelerating rate of unemployment

${ }^{13}$ Beside the univariate HP filter, band-pass filer are often used, too, especially Baxter-King filter a Christiano-Fitzgerald filter. Both filters were mentioned above.
} 
Output gap for the Czech Republic estimated with the production function using NAIRU is shown in the Figure No. $2^{14}$.

Figure 2: Output gap - version 2.

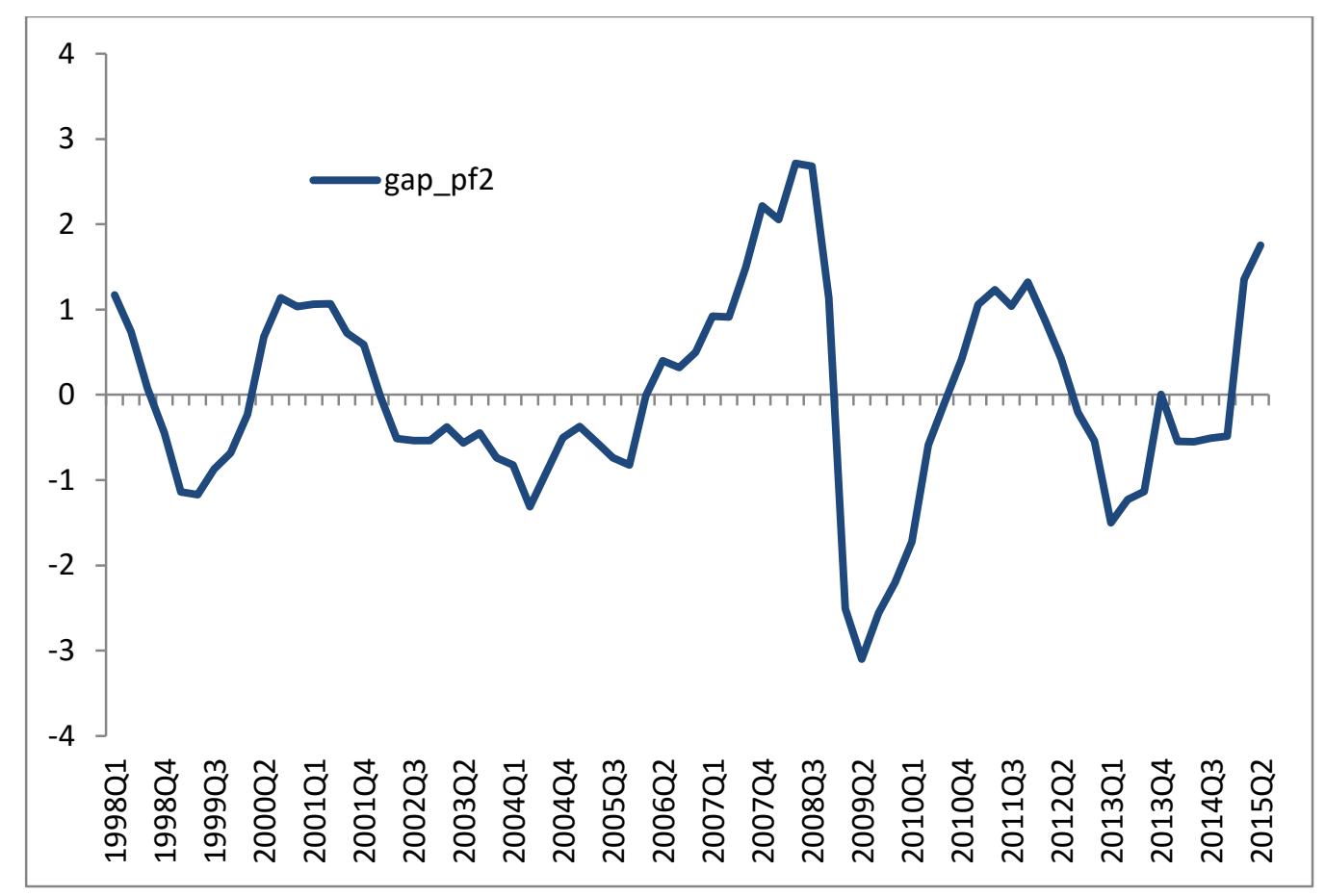

Source: author's own figures, data from OECD

\section{Comparisons}

Finally, it is possible now to compare results of particular estimations. First of all, estimations of output gaps will be compared in Figure No. $3^{15}$. One can see that both methods of estimation did not bring absolutely the same estimations of the unobservable states of variables. Although there were some relative huge differences in particular time periods, the difference in general was not very significant for the whole time series. Also there did not happen that one of the methods of estimations of potential output and output gap would bring higher or lower values for the whole time series. So e.g. the higher negative output gap estimated during 2001Q4 - 2005Q2 was estimated by the production function using univariate HP filter, while the production function with the NAIRU estimated a higher positive output gap during 2010Q22012Q2. Both versions of the production function estimated potential output and output gap quite equally in the period of economic decrease caused by world economic crisis (except at the end of 2008, when the decrease of output gap by production function with HP filter was approximately 8 p.p. and by the production function with the NAIRU

\footnotetext{
${ }^{14}$ An abbreviation "gap_pf2" means output gap estimated according to the second version of production function.

15 The abbreviation "gap_pf1" means output gap estimated according to the first version of production function, gap_pf2 then the second one.
} 
only approximately 6 p.p.) but following positive output gap during economic increase was estimated higher by the version with NAIRU. During the analysed time period, there did not occur the situation that one of the methods of estimation would bring different time of maximal or minimal values during 1998Q1 - 2015Q2. Both methods estimated maximal value equally in 2009Q2 and maximal value in 2008Q1, but there was a higher difference between the estimations of the maximum than of the minimum (here the difference was quite small).

Figure 3: Output gaps - comparison

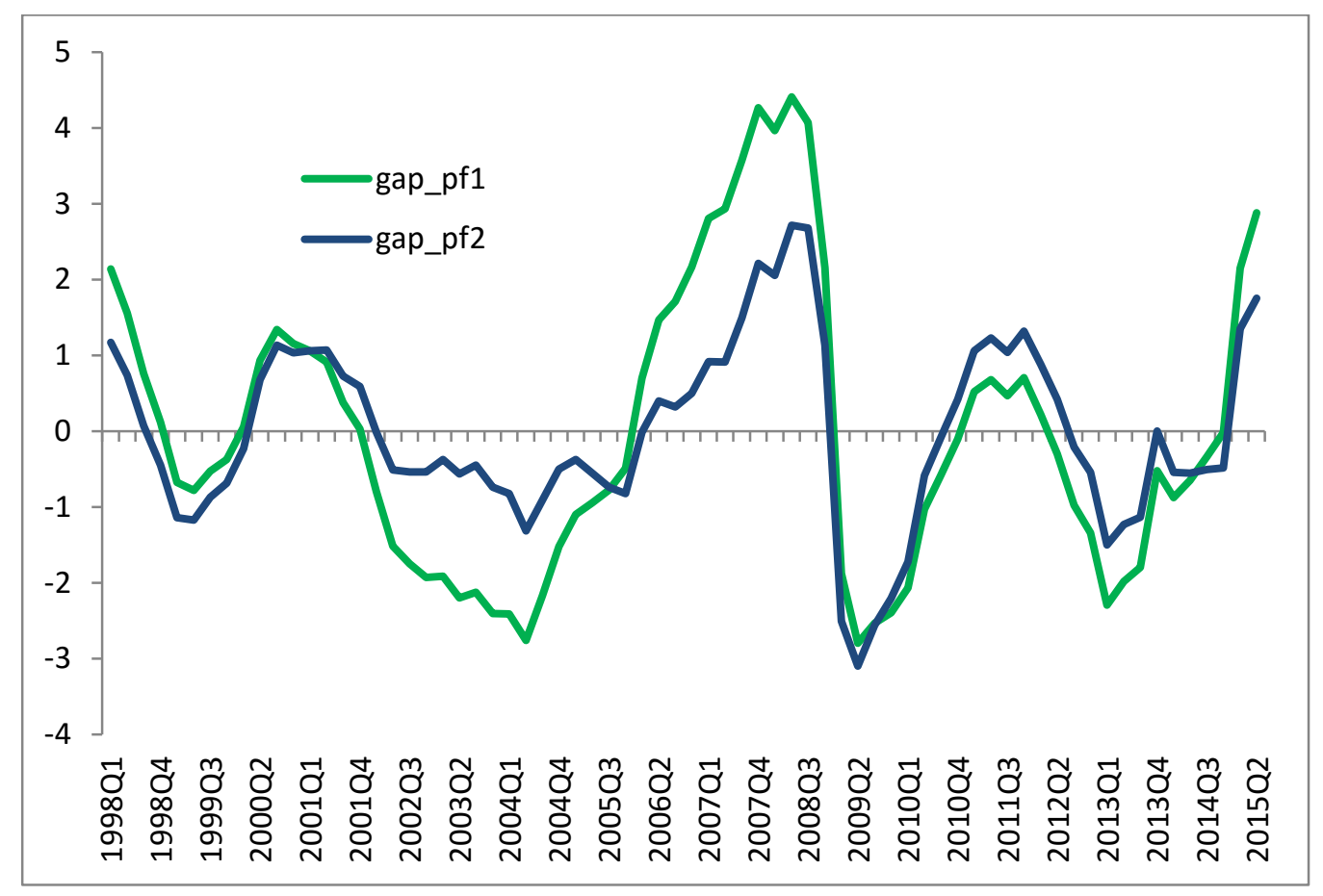

Source: author's own figures, data from OECD

Comparison of potential outputs estimated by the two versions of production function brings Figure No. $4^{16}$. It is possible to see that progresses of both potential outputs are very similar. Their smoothness was very similar, too. On the start of the analysed time period, obtained values of estimations have very similar progress. The higher difference between results of estimation occurred during approximately 2001Q4 2005Q3, when potential output estimated by the production function with the univariate HP filter has a lot higher values than potential product estimated by the production function with NAIRU, that means a higher negative output gap, too. During the economic expansion, approximately during 2007Q1 - 2009Q1, the version with the univariate HP filter estimated higher potential output. During following economic

\footnotetext{
${ }^{16}$ GDP means gross domestic product for the Czech Republic, pt_pf1 potential output estimated according to the first version of the production function, pt_pf2 a potential output estimated according to the second version of the production function.
} 
crisis, differences between potential outputs were not very substantial, only in the last two years, the version with NAIRU brought higher potential output than the version with univariate HP filter. This version estimated more optimistic prognosis of the progress of the Czech economy in following quarters, too.

Figure 4: Potential products - comparison

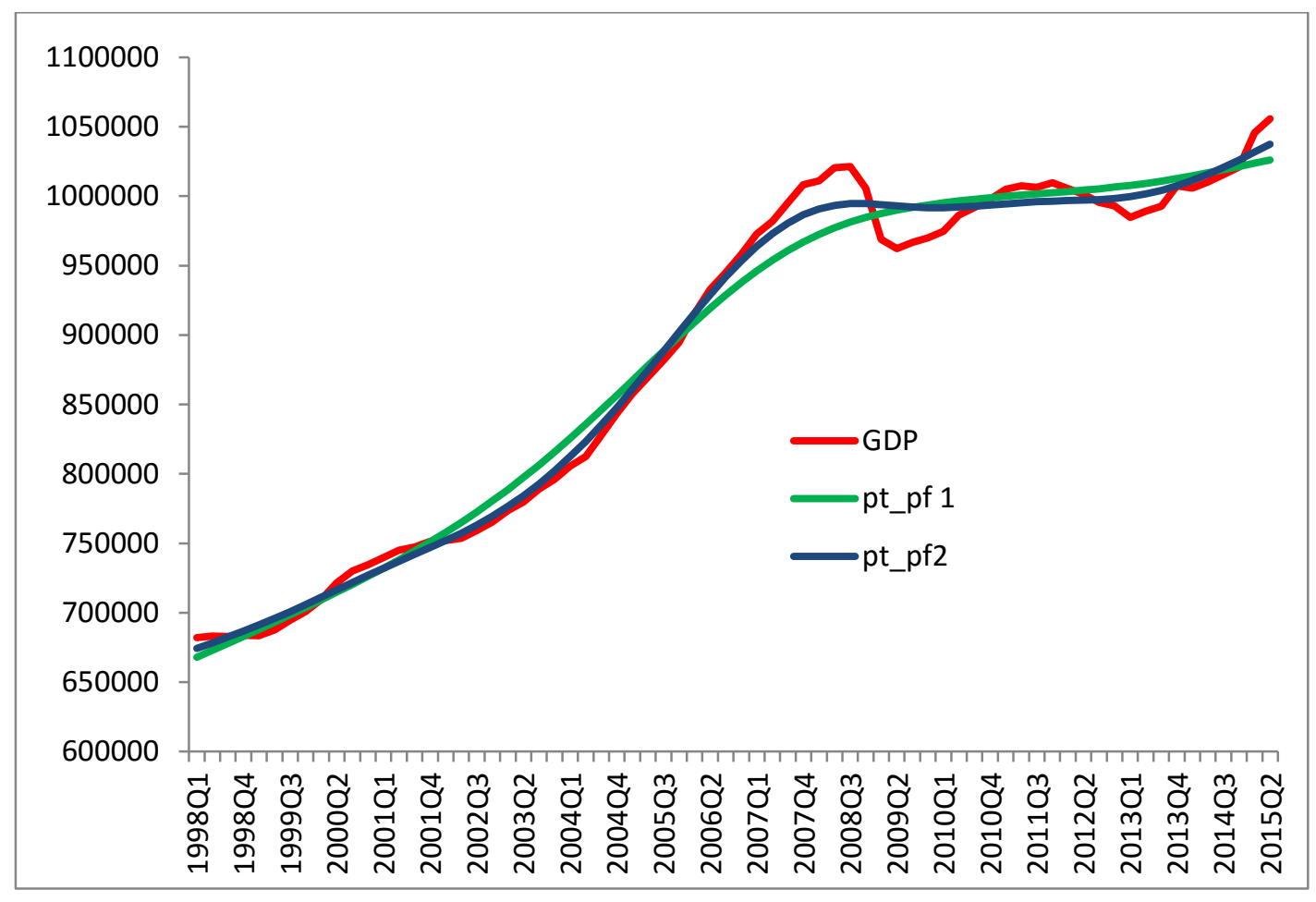

Source: author's own figures, data from OECD

Comparison of the growth of potential output calculated on the basis of obtained values of potential output estimated by the two versions of production function brings Figure No. $5^{17}$. Neither of the two methods estimated higher or lower growth for the whole analysed time series. The version with the univariate HP filter estimated higher growth of potential output in the beginning of analysed time period, but for following next five years, potential output estimated by the production version with the NAIRU grew faster than the one estimated with HP filter. Then, until the end of the year 2013, higher potential growth was estimated by the version with the univariate statistical filter. In the last two years, the version with the NAIRU estimated higher growth than the second version. In general, we can summarize that seasonally adjusted real output grew faster than both versions of potential output during the time period 1998Q1-2015Q2, 2.59\%. Higher growth of potential output estimated the version with the univariate HP filter, $2.56 \%$ but the version with the NAIRU did not bring very different results, either -

\footnotetext{
17 Pp1_growth means growth of the potential output estimated according to the first version of the production version, pp2_growth then the potential output estimated according to the second version of the production function.
} 
average growth of potential output was $2.55 \%$. In the end, we can conclude that using NAIRU instead of univariate HP filter will not lead to the very different results.

Figure 5: potential growth - comparison

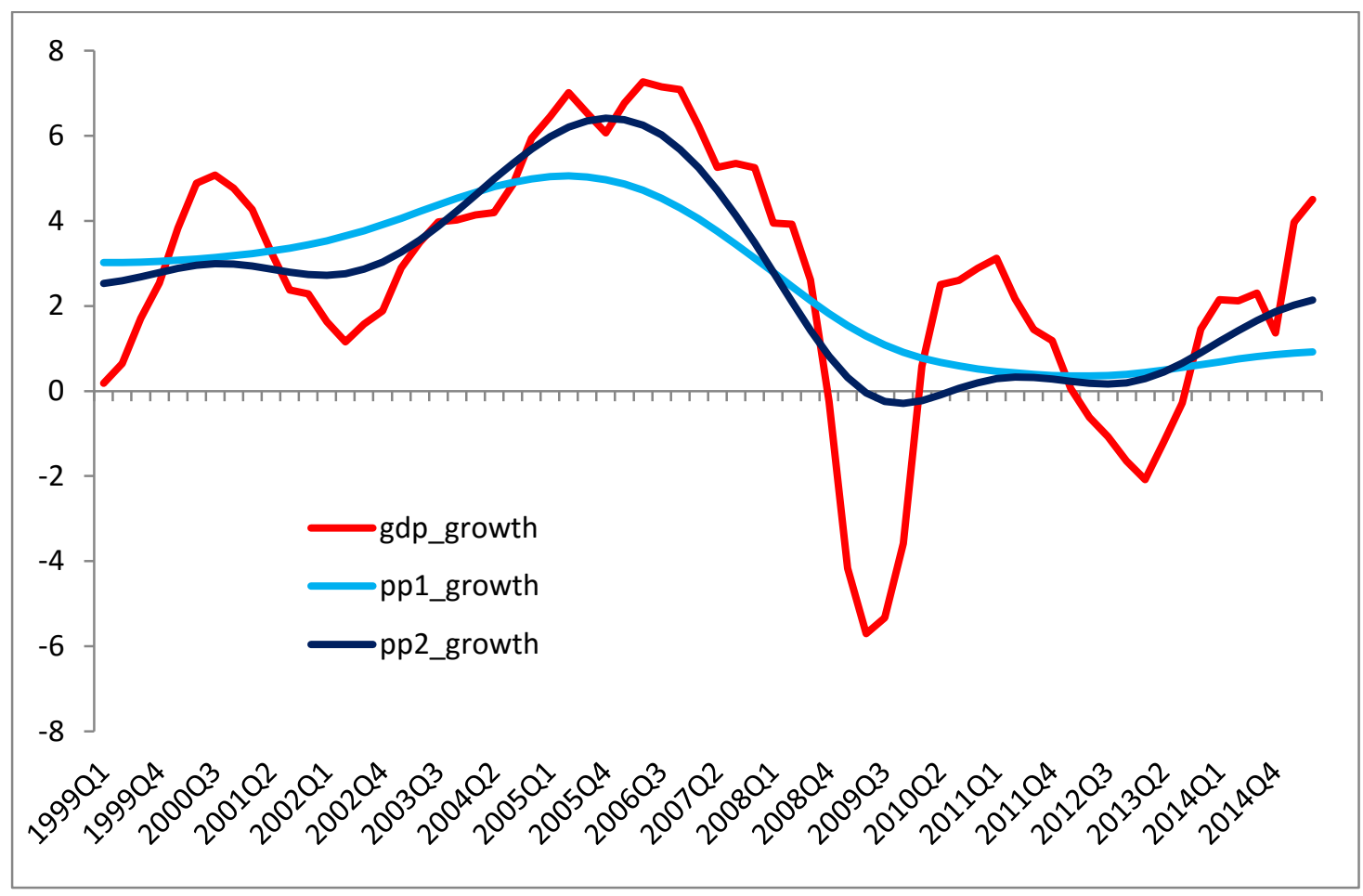

Source: author's own figures, data from OECD

\section{Other comparison and statistics}

To compare the output gaps estimated according to the two selected versions of the production function, other tests and statistics were added. The first selected indicator is a correlation. If there is a higher coefficient of correlation, we can suppose that there is quite a large similarity between the two variables. Correlation coefficient between the two versions of the output gaps was high, 0,9999. A concordance coefficient is a far less used nonparametric statistical indicator. If the concordance coefficient was 0 , there is a one version of output gap positive during the entire time period, and the second one is negative during the entire time period. The concordance coefficient for the two versions of the output gap for the Czech Republic was 0,865 . This a quite high number indicates that both versions estimated very similar output gaps.

The other statistics is shown in the table. No. 2. Average for both versions was very similar, the same holds for median and standard deviation. Quite higher difference occurred in minimal and maximal values, but in comparison to other studies dealing with the methods of estimation output gap, the differences were not very significant. 
Table No. 2: Statistics - comparison

\begin{tabular}{|ccc|}
\hline & gap_pf1 & gap_pf2 \\
average & $-0,023961$ & $-0,028646$ \\
median & $-0,38757$ & $-0,41618$ \\
minimum & $-3,8204$ & $-4,9623$ \\
maximum & 5,4763 & 7,7436 \\
st.dev. & 2,0308 & 2,8901 \\
\hline
\end{tabular}

Source: author's own figures, data from OECD

One of the advantages of the production function is its possibility to calculate the contributions of variables (total factor productivity TFP, labour $L$ and capital) to the growth of potential product. The contributions of variables to the growth of potential product are shown in the tables No. 3 and 4. To make the table more transparent, the quarterly data were re-count on the annual data, and only for years 2011-2014. If we looked at the two tables, we would see that there are not big differences between the two versions of estimation output gaps. The growth of the potential output were the same in the years 2013 and 2014. The difference in the years 2011 and 2012 between the two versions of estimation was only $0,1 \mathrm{pp}$. The less difference occurred in the total factor productivity (TFP). Both versions estimated the same values for all years 2011, 2012, 2013 and 2014. As for the labour, the difference in the contribution of labour to the growth of potential output occurred only in the year 2012. In the other years, the values were the same. The difference in contribution of capital to the potential output occurred only in the year 2011. To sum up the analysis, there were only insignificant differences in contribution of particular variables to the growth of the potential output. These results confirm that there are not big differences between the two output gaps estimated by the two versions of the production function. 


\section{Table No. 3: Average annual growth of potential product and particular contributions to the growth - production function 1}

\begin{tabular}{|ccccc|}
\hline & PP & TFP & $\mathrm{L}$ & Capital \\
2011 & 0,6 & 0,1 & 0,5 & $-0,1$ \\
2012 & 0,7 & 0,1 & 0,5 & 0,1 \\
2013 & 0,6 & 0,2 & 0,5 & 0,2 \\
2014 & 0,7 & 0,1 & 0,5 & 0,1 \\
\hline
\end{tabular}

Source: author's own figures, data from OECD

\section{Table No. 4: Average annual growth of potential product and particular contributions to the growth - production function 2}

\begin{tabular}{|ccccc|}
\hline & PP & TFP & $\mathrm{L}$ & Capital \\
2011 & 0,7 & 0,1 & 0,5 & 0 \\
2012 & 0,6 & 0,1 & 0,4 & 0,1 \\
2013 & 0,6 & 0,2 & 0,5 & 0,2 \\
2014 & 0,7 & 0,1 & 0,5 & 0,1 \\
\hline
\end{tabular}

Source: author's own figures, data from OECD

\section{Conclusion}

This paper analysed output gap and potential output that are very important macroeconomic variables used by central banks thanks to their ability to analyse business cycle or to predict progress of inflation in next quarters. Although they are very important for policy makers, there is a problem with their measurability because they are not able to be calculated with absolutely accuracy. Incorrectly estimated data are used in other macroeconomic calculations which can lead to incorrect evaluation of economic situation or prognosis. Therefore it is very important to use the most reliable method of estimation of these two variables. 
The aim of this paper was to analyse the estimations of output gap and potential output for the Czech economy with the production function which still belongs among the most frequently used methods of estimation of these unobservable variables. It was researched if using of univariate statistical filter, HP filter, which is often used by calculation of potential variables (e. g. potential employment) is less suitable for the estimations themselves. The second chosen version of production function was the one with the NAIRU which was used by the calculation of the potential employment.

The length of the analysed time series was from 1998Q1 to 2015Q2, thus 66 quarters. The parameters $\alpha$ and $\beta$ were determined to be constant for the whole time series. The results confirmed that obtained estimations did not bring the absolutely identical trajectories of the unobservable states, nevertheless there were not very significant differences between the two obtained estimations. Also there did not occur the situation that two methods of estimation brought different progress of business cycle (like in other studies for other economies). The maximal and minimal values were realized in the same quarters, only every version of production functions estimated different values. There was not a situation that one method estimated higher output gap for the whole time series. So e. g. production function with HP filter estimated higher positive output gap during 2006Q1 - 2009Q1, while production function with the NAIRU estimated higher positive output gap during 2010Q2-2012Q2. To make the analysis more precious, the growth of the potential output calculated on the basis of estimations of potential output were realised, too. It was shown that both versions brought very similar values of average growth of potential product: a production function with HP filter estimated average growth $2.56 \%$, while the version with the NAIRU $2.55 \%$.

Other statistics confirmed the similarities, too. The correlation coefficient was high, 0,999 . The concordance coefficient 0,865 indicated that both output gaps had a very similar progress. Other statistical indicator confirmed this result. Contributions of total factor productivity, labour and capital to the growth of the potential output were calculated, too. It was shown, that contributions of these variables calculated by the two versions of the production function were not very different.

According to the realized research it is possible now to conclude that using the version of production function with NAIRU will not bring very different results from using the production function with the univariate HP filter.

\section{Literature}

ARTUS, J. R. (1977). „Measures of potential output in manufacturing for eight industrial countries, 195578.“. IMF Working Paper Vol. 24, No. 1, pp. 1-35.

BAXTER, M. a KING, R. (1999). „Measures Business Cycles: Approximate Band - Pass Filters for Economic Time Series“. Review of Economics and Statistics Vol. 84, 575 - 593. 
BENEŠ, J.; N'DIAYE, P. 2004. A Multivariate Filter for Measuring Potential Output and the NAIRU: Application to the Czech Republic. .[ IMF Working Paper No. 04/45]. International Monetary Fund, 2004.

BEVERIDGE, S.; NELSON, C. R. (1981). „A new approach to the decomposition of economic time series into permanent and transistory components with particular attention to measurement of the business cycle." Journal of Monetary Economics, 7, pp. 151 - 174.

CERRA, V. a Saxena S. C. (2000). „Alternative Methods of Estimating Potential Output and Output Gap: An Application to Sweden“, IMF Working Paper 00/59.

CHAGNY, O. and DÖPKE, J. (2001). "Measures of the output gap in the euro-zone: an empirical assessment of selected methods." Kiel Working Paper No. 1053, 2001.

CHRISTIANO, L. J. a FITZGERALD, T. J. (1999). „The Band Pass Filter.“ Federal Reserve Bank of Cleveland Working Paper 99/06.

DE BROUWER, G. (1998). „Estimating Output Gaps“, Reserve Bank of Australia Research Discussion Paper No. 9809.

BOLT, W. and van ELS, P.J.A. (1998). "Output gap and inflation in the EU." De Nederlandsche Bank Working Paper. PP. 1-32.

CUI, W., HÄRDLE, W.K. and WANG, W. (2015). "Estimation NAIRU with Inflation Expectation Data." SFB 649 Discussion Paper, No. 010.

DE MASI, P. (1997). „IMF Estimates of Potential Output: Theory and Practise.“ IMF Working Paper No.WP/97/177.

DENIS, C.; GRENOUILLEAU, D.; McMORROW, K. a RÖGER, W. (2006). „, Calculating potential growth rates and output gaps-A revised production function approach." European Commision, Economic papers No. 247.

DOMENECH, R. and V. GOMEZ, 2003, "Estimating potential output, core inflation and the NAIRU as latent variables", University of Valencia, mimeo.

DYBCZAK, K,; FLEK, V.; HÁJKOVÁ, D. a HURNÍK, J. (2006). „Supply-Side Performance and Structure in the Czech Republic (1995-2005)." Czech National Bank Working Paper No.4.

EPSTEIN, N. a MACCHIARELLI, C. (2010). „Estimating Poland's Potential Output: A Production Function Approach." IMF Working Paper No. WP /10/15.

FABIANI, S. a MESTRE, R. (2004). „A systém approach for measuring the euro area NAIRU.“ Empirical Economics, No. 29, pp. 311-341.

GIORNO C.; RICHARDSON, P.; ROSEVEARE, P. a VAN DEN NOORD, P. (1995). „Estimating potential output, output gaps and structural budget balances." OECD Economics Department Working Paper No. 152.

GORDON, R. J. (1996). "The time-varying NAIRU and ots Implications for Economic Policy.“ NBER Working Paper No. 5735. 
HÁJEK, M.; BEZDĚK, V. 2000. „Odhad potenciálního produktu a produkční mezery pro ČR.” [ČNB VP č. 26]. ČNB, 2000.

HÁJKOVÁ, D. a HURNíK, J. (2007). „Cobb-Douglas Production Function: The Case of a Converging Economy." Czech Journal of Economics and Finance, Vol.57, No. 9-10, pp. 465-476.

HJELM, G. a JÖNNSON, K. (2010). , In search of a method for measuring the output gap of the Swedish economy. Economic, econometric and practical considerations." The National Institute of Economic Research Working Paper No. 115.

HODRICK, R.J. a PRESCOTT, E.C. (1997). „Post-war U.S. Business Cycles: An Empirical Investigation“. Journal of Money, Credit and Banking, Vol. 29, No. 1, pp. 1-16.

HURNÍK, J; NAVRÁTIL. D. (2005). "Potential Output in the Czech Republic: A Production Function Approach." Prague Economic Papers, Vol. 2005, No. 3, pp. 253-266.

KENNY, G. (1995). „Some Estimates of Potential Output and the Output Gap for Ireland“, Central Bank of Ireland Technical Paper Series No. 5/RT/95.

KLOUDOVÁ, D.(2013a). "Produkční mezera jako indikátor inflace - případ pro českou ekonomiku." Politická ekonomie, Vol. 2013, No. 5, pp. 639-652.

KLOUDOVÁ, D. (2013b). "Modely nepozorovaných komponent pro odhad produkční mezery české ekonomiky." Acta academica karviniensia, 2013, Vol. 16, No. 3, pp. 95-105.

KONUKI, T. 2008. Estimating Potential Output and the Output Gap in Slovakia. ? [IMF Working Paper WP /08/275]. International Monetary Fund, 2008.

MOURRE, G. (2009). , What explains the differences in income and labour utilisation and drives labour and economic growth in Europe? A GDP accounting perspective." European Commision, Economic papers No. 354.

OKUN, A. M. (1962). „Potential GNP: Its Measurement and Significance.“ In Proceedings of the Business and Economics Statistics Section. Washington, DC: American Statistical Association, 1962, pp. 98-104.

OOMES, N. a DYNNIKOVA, O. (2006). „The Utilization-Adjusted Output Gap: Is the Russian Economy Overheating?"IMF Working Papers No.WP/06/68.

PLAŠIL, M. 2011. Potenciální produkt, mezera výstupu a míra nejistoty spojená s jejich určením při použití Hodrick-Prescottova filtru. Politická ekonomie, Vol. 2011, No. 4, pp. 490-507.

SLEVIN, G. (2001). „Potential Output and the Output Gap in Ireland“ , Central Bank of Ireland Technical Paper Series, No. 5/RT/01.

SRAMKOVA, L. (2010). "Output Gap and NAIRU Estimates within State-Space Framework: An Application to Slovakia". Financial Policy Institute of The Ministry of Finance of the Slovak Republic, No. 2.

ST. AMANT, P. and VAN NORDEN, S. (1997). "Measurement of the Output Gap: A Discussion of Recent Research at the Bank of Canada. Bank of Canada Technical Report No. 79. 
BOLT, W. and van ELS, P.J.A. (1998). "Output gap and inflation in the EU." De Nederlandsche Bank Working Paper. PP. 1-32.

ZIMKOVÁ, E.; BACHOROVSKÝ J. 2007 Odhad potenciálního produktu a produkčnej medzery v slovenských podmienkach, Politická ekonomie, Vol. 2007, No. 4, pp. 473-489. 